\title{
TECHNOPOLITICAL APPROACHES ON THE RECENT GLOBAL SOCIAL MOVEMENTS
}

\author{
ABORDAGENS TECNOPOLÍTICAS DOS RECENTES MOVIMENTOS SOCIAIS \\ GLOBAIS
}

\section{ENFOQUES TECNOPOLÍTICOS SOBRE LOS RECIENTES MOVIMIENTOS SOCIALES GLOBALES}

\author{
JESÚS SABARIEGO \\ sabariego@ces.uc.pt \\ Centro de Estudos Sociais, University of Coimbra, Portugal and University of Seville. \\ Sevílha, Espanha.
}

\begin{abstract}
This article analyzes the social movements that have emerged in the context of the global crisis since 2011, as the symptoms of the erosion of human rights and the democratic deficit imposed by the neoliberal policies of the last decades, especially increased in recent years through the local, national and European institutional agendas. Grounded in the impact of these movements on public opinion and its irruption in the institutions via elections, especially in Southern Europe and paradigmatically in two of the european countries most affected by these policies, as Portugal and Spain and allied to a decentred study of the tactical extensive media-crossed political use of the Information and Communication Technologies (ICTs) by these movements, the text shows a complex new political scenario in these countries, that allow us to propose a new key-category in the theory of social movements: Recent Global Social Movements (RMSGs).
\end{abstract}

Keywords: Recent Global Social Movements; Technopolitics; Internet Social Media; Private Internet Messages Services; Common-based Democracy.

\section{RESUMO}

Este artigo analisa os movimentos sociais que emergem no contexto da crise global desde 2011, como os sintomas da erosão dos direitos humanos e o déficit democrático imposto pelas políticas neoliberais das últimas décadas, especialmente aumentados nos últimos anos através das agendas institucionais da comunidade local, nacional e europeia. Fundamentado no impacto desses movimentos na opinião pública e em sua irrupção nas instituições por meio de eleições, especialmente no sul da Europa e paradigmaticamente em dois dos países europeus mais afetados por essas políticas, como Portugal e Espanha, e aliados a um estudo descentralizado da tática do uso político das tecnologias da informação e comunicação (TICs), atravessado pela mídia, por esses movimentos, o texto mostra um novo cenário político complexo nesses países, que nos permite propor uma nova categoria-chave na teoria dos movimentos sociais: Global Recente Movimentos Sociais (RMSGs).

Palavras-chave: Movimentos sociais globais recentes; Tecnopolítica; Mídias sociais na Internet; Serviços de mensagens privadas na Internet; Democracia comum.

\section{RESUMEN}

Este artículo analiza los movimientos sociales que han surgido en el contexto de la crisis mundial desde 2011, como los síntomas de erosión de los derechos humanos y el déficit democrático impuesto por las políticas neoliberales de las últimas décadas, especialmente aumentado en los últimos años a través de las agendas institucionales de la comunidad local y nacional. y europeo. Basado en el impacto de estos movimientos en la opinión pública y su interrupción en las instituciones a través de las elecciones, especialmente en el sur de Europa y paradigmáticamente en dos de los países europeos más afectados por estas políticas, como Portugal y España, y aliados a un estudio descentralizado de tácticas 
Sobre el uso político de las tecnologías de la información y la comunicación (TIC) atravesadas por los medios de comunicación por estos movimientos, el texto muestra un nuevo escenario político complejo en estos países, que nos permite proponer una nueva categoría clave en la teoría de los movimientos sociales: movimientos recientes globales Problemas sociales (RMSG).

Palabras clave: Recientes movimientos sociales mundiales; Tecnopolítica; Medios sociales de internet; Servicios privados de mensajes de Internet; Democracia de base común.

\title{
SUMMARY
}

1 CTRL+ALT+INTRO; 2 CTRL+ALT+SHIFT; 3 CTRL+ALT+DELETE; REFERÊNCIAS.

\author{
I like to think \\ (it has to be!) \\ of a cybernetic ecology \\ where we are free of our labors \\ and joined back to nature, \\ returned to our mammal \\ brothers and sisters, \\ and all watched over \\ by machines of loving grace.
}

Richard Brautigan, Machines of loving grace (1967)

\section{CTRL+ALT+INTRO}

Some recent interpretations of the technopolitics, concerning the appropriation and mediation of Information and Communication Technologies (ICTs) that make social movements, characterise these processes as if a new Prometheus (Barney, 2000 and Milan, 2013, Sierra and Gravante, 2018 and Sabariego, 2018) had stolen a digital fire from the media gods of Olympus or even defined ICTs and Internet Social Media roles as a 2.0 metaphor of the machine of the industrial revolution.

Information and communication technologies (ICTs by its acronym) are strategic elements when attempting to understand the upsurge of these movements, highlighting the impact of Internet Social Media (ISM) and Private Internet Messenger Services (PIMS) in public awareness, on the basis of a new and practically virgin academic-scientific field: Technopolitics, defined here as the appropriation of ICTs, ISM and PIMS by social movements for political purposes and the impact that this is having on the institutional sphere in the technological transition, not only with respect to election campaigns and political agendas, but also as a strategic dimension when researching 
into the very representation, identity and culture of these movements and their influence on the public sphere.

Informationalism has traversed its development phase and has been hit with a major series of industrial and financial crises beginning in the year 2000 and culminating in 2007-08, with fiscal crises of the states and municipalities still to come. The financial crises have been accompanied by crises in capital-labor relations, cultural upheavals and inter-state conflicts. The attempt to replace welfare-state financing of consumption by corporate-managed credit has broken down and what is at stake now is either a continuing slide into economic chaos, or the invention of a new strategy for the stabilization of the transnational class structure generated by networked technologies. Workers' autonomy - and maybe something like middle-managers' autonomy reappears with the cycle of counter-globalization struggles beginning in 1999, but is limited by the deep fragmentation of the global division of labor.

To support the failing electronics markets and reassert control after a decade of extreme deterritorialization, the state invests heavily in surveillance and sorting technologies. One culturalized component of contemporary class struggle, Islamism, is systematically exacerbated by transnational elites in a bid to re-legitimate police and military authority and to thwart any global articulation of oppositional movements.

The notion of cloud, already present in Buckminster Fuller's sci-fi stories, and linked since 2011 to protests (Milan, 2013: 889) around the world arises in the current context of the crisis of representation and formal democracy and in the face of the spread of populist movements and the social challenges of building inclusive societies, grounded in equality and the respect for diversity and differences, the commitment to human rights and democracy are both central aspects, understood in terms of citizen participation in the creation of institutions and a political agenda based on knowledge and social innovation, which I termed as a commons-based democracy. 


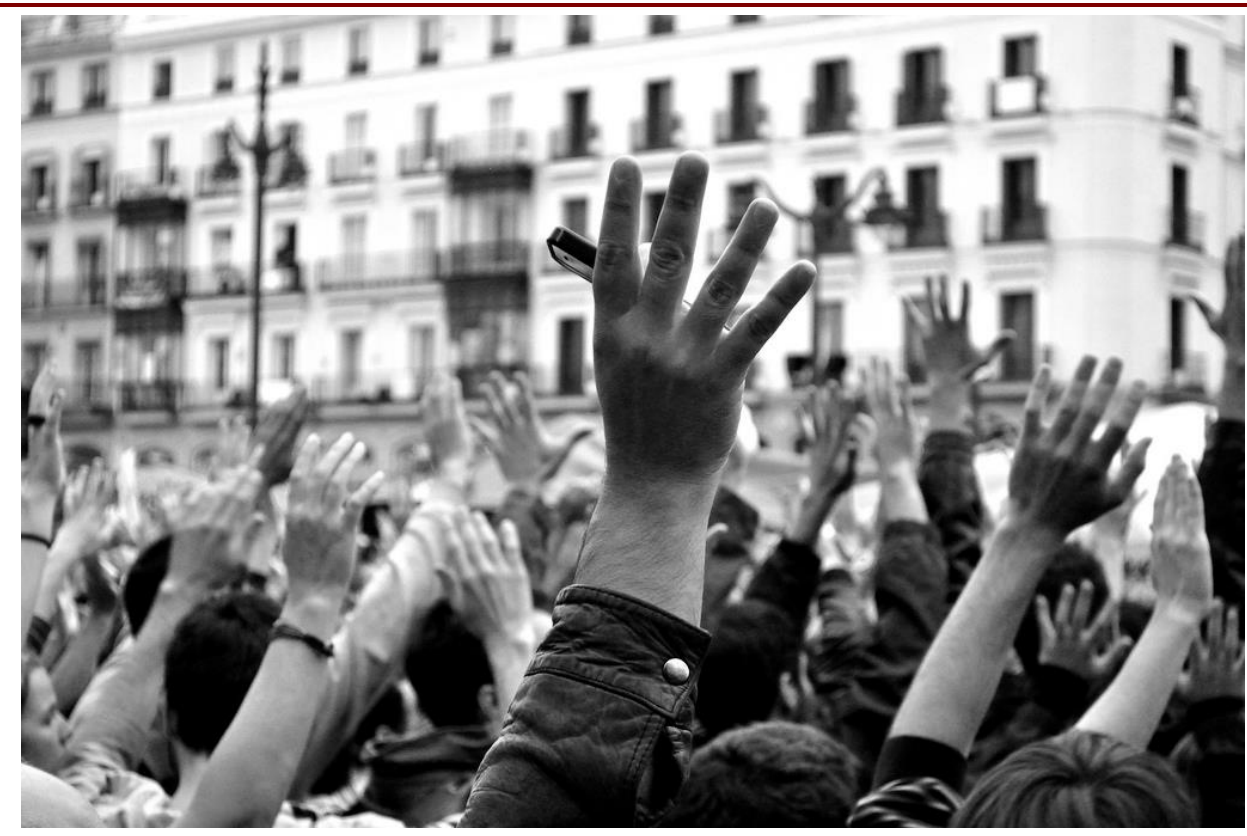

Source: 15M Movement, Madrid, Puerta del Sol (Spain)

In Europe, these mentioned processes, underscore how the passive role of citizens has been transformed by introducing a proactive dimension, characterized by participation and even by the possibility of updating established politics by actively contributing to create new political agendas. This situation has been compounded by the problems to consolidate a European public sphere (Salovaara-Moring, 2012), such as the Juncker Commission's priorities relating to security states and the promotion of common values of freedom, tolerance, Human rights and democracy beyond the success of any shared experiences and memories of a small number of EU citizens, through effective EU policy-making, highlighting the key role that ICTs and ISM play in interactions among institutions, the citizenry, social movements and public awareness against national media as the traditional and hegemonic area of Europeanization:

The distributed collective expression of contention - for instance, in protests that have spilled over from their original locales such as the Arab Spring, the Indignados and the Occupy Movements - testifies to the amplification of the political as defined by Chantal Mouffe (2000). The political is an essential attribute of communication to the extent that it references one of its key purposes, namely to regulate action thereby consigning conflict to the sphere of symbolic exchanges. An exhaustive taxonomy of individual or collective forms of political expression is impracticable, subject to perpetual revision and endlessly assailable with reproofs of its impact on institutional politics (Jenkins \& Carpentier,_2013, p. 269) or the media (Castells,_2007; Gamson et al.,_1992). Hinting at a line of enquiry that might 
ISSN 1981-3694

(DOI): $10.5902 / 1981369440999$

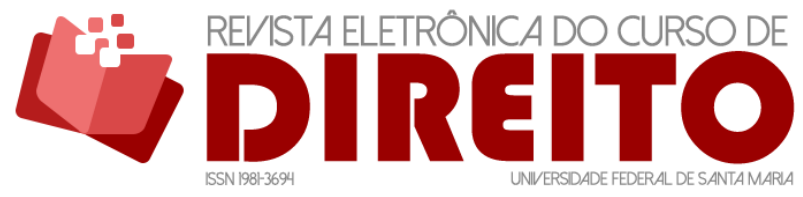

TECHNOPOLITICAL APPROACHES ON THE RECENT GLOBAL

SOCIAL MOVEMENTS

JESÚS SABARIEGO

steer the debate on impact ${ }^{1}$ beyond the current scepticism that has helped to reify social media, in particular, as a vector for social change, Lance Bennett raised the following question: Where did the ideas [at the heart of] ... large protests like the Arab Spring or Occupy Wall Street ... come from? I think that ideas are important in democracy. Ideas that motivate people. Ideas that give people a guidebook for change and for political organisation ... I am interested in where new ideas come from and what the future of democracy looks like when those ideas come along. (24 June_2015)" (Dan Mercea ${ }^{a^{*}}$, Laura lannellib \& Brian D. Loader $\left.{ }^{c,}, 2016\right)$.

The spreading of glocalisation and the information society have made possible the development of new forms of online participation, exchange of social knowledge (Bennett and Segerberg, 2011), learning experiences and activism in a "wired" world with a consistent impact in mainstream media:

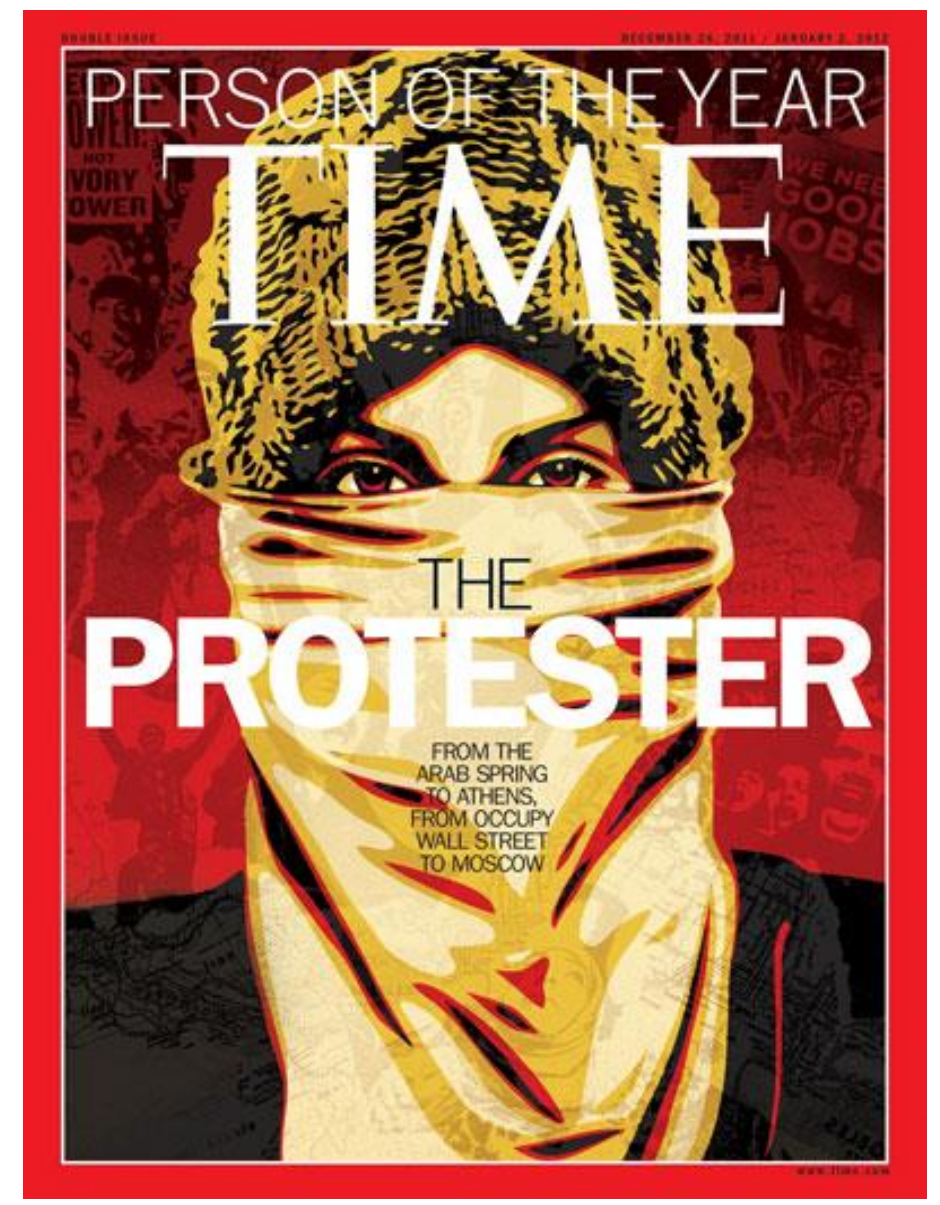

Source: @ Time Magazine, 2011.

\footnotetext{
${ }^{1}$ Bold highlight mine.
} 
As Saskia Sassen have defined those movements as a strategic elemento to characterize what she named the global street (Sassen, 2011: 573-74):

Street struggles and demonstrations are part of our global modernity. The uprisings in the Arab world, the daily neighborhood protests in China's major cities, Latin America's piqueteros and poor people demonstrating with pots and pans-all are vehicles for making social and political claims. We can add to these the very familiar anti-gentrification struggles and demonstrations against police brutality in US cities during the 1980s and in cities worldwide in the 1990s and continuing. Most recently, the over 100,000 people marching in Tel Aviv-a first for this city-not to bring down the government, but to ask for access to housing and jobs; part of the demonstration is Tel Aviv's tent city, housing mostly impoverished middleclass citizens. The Indignados in Spain have been demonstrating peacefully in Madrid and Barcelona for jobs and social services; they have now become a national movement with people from through-out Spain gathering to go on a very long march to EU headquarters in Brussels. These are also the claims of the 600,000 who went to the street in late August in several cities in Chile. These are among the diverse instances that together make me think of a concept that takes it beyond the empirics of each case-The Global Street.

The social movements (SMs) that have emerged in the context of the economic crisis, defined in other work of mine (Sabariego, 2018) as Recent Global Social Movements (RGSMs) and which are calling for real participation in a real democracy, have had a considerable impact on the EU, above all in Southern Europe, underlying the case of Portuguese Movimento 12 de Março (M12M) and the Spanish Movimiento 15 de Mayo (15M).

These movements have contributed to spread a conception of a commons-based democracy (Bollier and Helfrich, 2012), focused in the sphere of the city and the local politics with results in local elections (e. g. Barcelona en Comù and Madrid Ahora, in Spain), which emphasizes its social dimension, self-government on the basis of a decision-making capacity, deliberation and participation (Di Robilant, 2012). In these sense, as Sassen has highlighted (2011: 574):

In each of these cases, I would argue that the street, the urban street, as public space is to be differentiated from the classic European notion of the more ritualized spaces for public activity, with the piazza and the boulevard the emblematic European instances. I think of the space of 'the street', which of course includes squares and any available open space, as a rawer and less ritualized space. The Street can, thus, be conceived as a space where new forms of the social and the political can be made, rather than a space for enacting ritualized routines. With some conceptual stretching, we might say that politically, 'street and square' 
are marked differently from 'boulevard and piazza': The first signals action and the second, rituals.

\section{CTRL+ALT+SHIFT}

Research into the relationship between ICTs and politics and social movements began in the middle of the last decade by analyzing the activity of bloggers and websites, while the first tentative approach to the potential political uses of Facebook was made a decade later (Zappavigna, 2012).

Even though they offered comparative and complementary perspectives to critical discourse analysis (CDA), these research projects have regarded discourse "as [a] general social phenomenon rather than investigating particular linguistic patterns in political discourse" (Zappavigna, 2012: 170) or directly studying it as an expression of public opinion on ISM, which is one of the innovative contributions of my methodological proposal (Kahn y Kellner, 2004: 87-8):

In the late 1990s, such activists began employing the internet to foster affiliations and stage events against the excesses of neoliberalism and transnational corporate capitalism. Beginning with the 18 June 1999 'Carnival Against Capital!' demonstration that covertly organized hundreds of thousands of protesters (including labor, environmentalist, feminist, anti-capitalist, animal rights, anarchist, and other groups) throughout the world to demonstrate in newfound solidarity, the Carnival continued with the infamous 'Battle for Seattle' against the World Trade Organization (WTO) meeting in December 1999. Thus, an international protest movement surfaced in resistance to neoliberal institutions and their related globalization policies, while democracy, social justice, and a better world were championed. Since then, broad-based, populist political spectacles have become the norm, thanks to an evolving sense of the way in which internet may be deployed in a democratic and emancipatory manner by a growing planetary citizenry that is using the new media to become informed, to inform others, and to construct new social and political relations. 


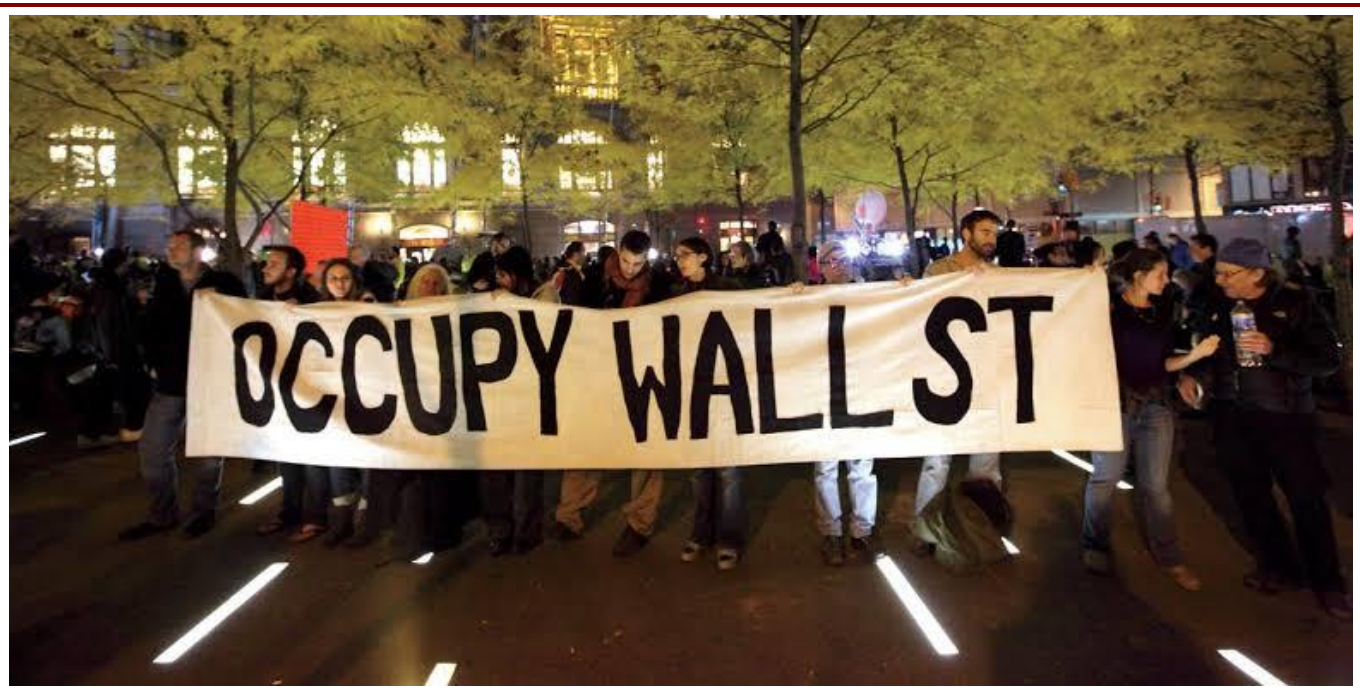

Source: Occupy Wall Street, New York City (USA)

Over the past few decades, the EU has dealed with the possibilities for the existence of a public sphere (Öffentlichkeit) in a post-Westphalian and post-national Europe (Habermas, 1998 and their critiques, especially from feminist theory, Sassen, 1998 and Fraser, 2007 among others).

The European refugee crisis and migratory policies have redefined these possibilities in the agenda of organizations and political parties in which a return to nationalism has marked a turning point that should be taken into account. (Accornero y Pinto, 2015: 508):

\begin{abstract}
The new social movements we charted in relation to the broader field of antiausterity politics in Portugal certainly do evidence many interesting and novel characteristics: their mode of mobilisation does rely extensively on ICT; their discourse makes original identity claims based on traditionally silent vectors (informal or insecure employment, the idea of a 'generation'); and they do advocate, in many cases, non-hierarchical forms of mobilisation and participation. On the other hand, our data suggests that these movements' ability to mobilise extensively has been sporadic and discontinuous. In part this may be connected to the relative absence of a long-established autonomous infrastructure of civil society -Portuguese 'new new' social movements have a relatively sparse network of autonomous social justice and campaigning social movement organisations from which to draw support, expertise and members. As such, these movements may be less rooted in their constituency than is often suggested.
\end{abstract}

In every case, from Tunisia to United States of America, Turkey to Brazil, Greece, Portugal or Spain, among other geographies, collective action in public space has been intensified, giving rise to diverse forms of politicisation from below related to shared social struggles and developed mainly in local and national scopes but linked globally over the Internet (Sierra and Gravante, 2018). 
ISSN 1981-3694

(DOI): $10.5902 / 1981369440999$

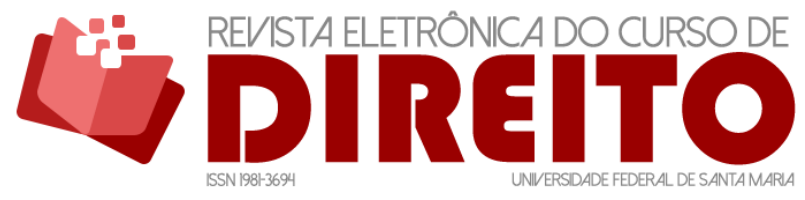

TECHNOPOLITICAL APPROACHES ON THE RECENT GLOBAL

SOCIAL MOVEMENTS

JESÚS SABARIEGO

Since 2011, diverse social movements (SMs) have come forward in different parts of the world against the background of the global crisis (Toussaint, 2012; Badiou, 2012; Castells, 2012 and Byrne, 2012).

In the Portuguese case, a feature that became evident, and it seems to be common to all this cycle of protest, is the return of material issues as central elements of political mobilization and struggle identity formation. Transformations in work, characterized mainly by the installation of unprecedented unemployment and a rampant process of precarization of labour relations, are now deepened by the dynamics introduced by austerity policies whose effects are cutting wages and social benefits, shrinking social functions of the state and the worsening of the debt problem, resulting from the transformation of a financial crisis in a crisis of sovereign debts of the states. March 12 was the moment of expression of a general discontent, which addresses not only the functioning of economy, but it is revealing, too, a crisis of legitimacy of political institutions. Indeed, if this cycle of protest began with movements for democracy in the Arab world, whose political regimes were clearly authoritarian, its expression in the countries of Southern Europe, or the way they emerged on the other side of the ocean in the U.S., reveals a distrust of citizens regarding political institutions and the claim for a "real democracy", to use the expression of the Spanish Indignados. (Estanque, Costa et Soeiro, 2013: 16-7).

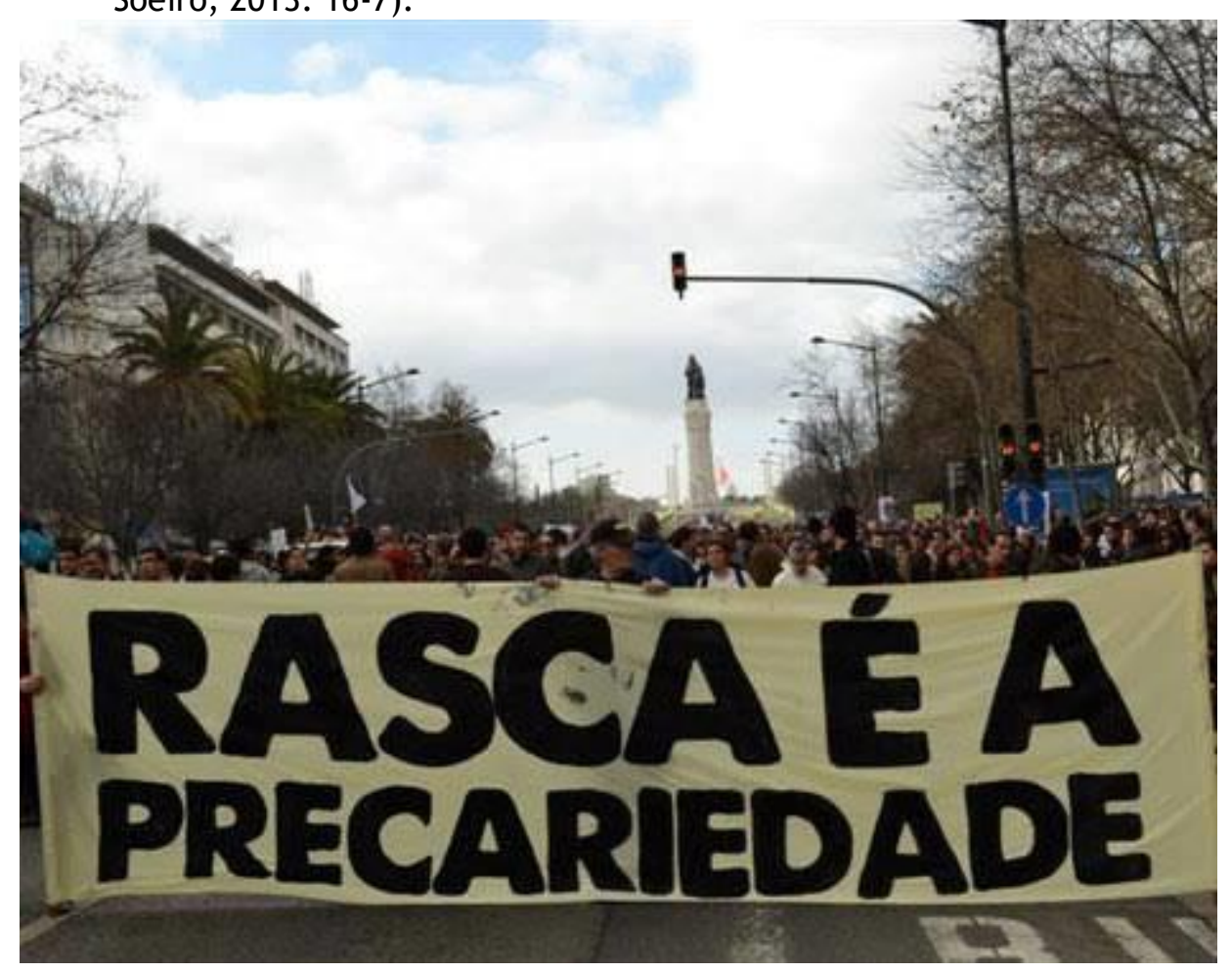

Source: Geração à rasca (12 de março Movement), Lisbon (Portugal)

A specific question in the Spanish case is the displacement of an important part of this forms of politicization to the electoral field, where the political cycle that begins with the emergence of 15M movement in May 2011 has permitted the aperture of a space for action out of 
the traditional bi-partisan system with the Partido Popular (PP) and the Partido Socialista Obrero Español (PSOE).

\section{CTRL+ALT+DELETE}

These processes have propitiated the appearance of new political parties and electoral platforms at national scope as Partido X, Podemos or Unidos Podemos (the electoral coalition between Podemos, Izquierda Unida, Equo and other leftist forces), while at local scope, the protest cycle has crystallised in the formation of citizen municipal candidatures which in the municipal election of 24 May 2015 have obtained notable achievements in the medium and largest cities as Barcelona, Madrid, Málaga, Cádiz, Zaragoza, Santiago de Compostela and A Coruña among others, taken into account the recent rise of the far-right forces.

The Recent Global Social Movements emerged in Portugal and Spain since 2011, contributed to create collective practices and founding spaces for a commons-based democracy as a political principle able to generate high intensity democratic experiences, such as listening, assembly and consensus behaviours, as well as collective behaviours of socialisation in which people support and coordinate themselves daily in order to stop evictions, to defend public health from privatisation, to denounce (escraches) banks and politicians who are made responsible for the crisis, co-creating a new global ecology of identification for Social Movements:

(...) in the participatory ecology ${ }^{2}$, audiences were elevated to the position of cocreators of social goods (Benkler,_2006). In their turn, interactive and participatory ecologies spin off their own mythos of a participatory culture unleashed with expressive, interactive and networked social media. (Dan Mercea ${ }^{\mathrm{a}^{*} \text {, }}$ Laura Iannellib \&_Brian D. Loader $\left.{ }^{c}, 2016\right)$.

Thus, a new space of social interrelation that escapes from the legal and political hegemonic limits of the public and the private is being built from common action. But is not only about building new narratives, a new lexicon or, it would be better said, a new counter-hegemonic hypertextuality.

\footnotetext{
${ }^{2}$ En el artículo, que sirve de introducción al número especial, enumeran tres ecologías, ambientes en sentido amplio, la del broadcast; interactive and participative.
} 


\section{REFERENCES}

Accornero, Guya and Ramos Pinto, Pedro (2014), "'Mild Mannered'? Protest and Mobilisation in Portugal in Times of Crisis", West European Politics, Volume: 38, 491-515.

Aguiló, Antoni. and Sabariego, Jesús (2016): “En soledad nos quieren, en común nos tendrán. The Municipalism from Below in the 24M elections in Spain: Towards a new politics of the common?", Revista de Historia Actual, Cádiz.

Alcazan et al. (2012), Tecnopolítica, internet y r-evoluciones. Sobre la centralidad de las redes digitales en el 15M. Barcelona: Icaria.

Alonso González, Marián (2015), "Nuevas tecnologías y cambio social: los yayoflautas se organizan en la red para generar transformaciones sociales.", Commons: Revista de comunicación y ciudadanía digital, 4 (. 1): 2-2.

Akrivopoulou, Christina y Garipidis, Nikolaos (2014), Human Rights and the Impact of ICT in the Public Sphere: Participation, Democracy and Political Autonomy. Hershey: IGI Global.

Aneesh, Aneesh (2012), "Informationalism", in VA, The Wiley-Blackwell Encyclopedia of Globalization. Londres: Wiley.

Aneesh, Aneesh; Petro, Patrice y Hall, Lane (co-eds.) (2011), Beyond Globalization: Making New Worlds in Media, Art, and Social Practices. Nueva Jersey: Rutgers University Press.

Anderson, Chris (2008), "The End of Theory: The Data Deluge Makes the Scientific Method Obsolete", Wired, 16, 1-2.

Ardanuy Pizarro, Miguel y Labuske, Eric (2015), “El músculo deliberativo del algoritmo democrático: Podemos y la participación ciudadana”, Teknokultura, 12 (1), 93-109.

Austin, John Langshaw (1982), ¿Cómo hacer cosas con palabras? Madrid: Paidós Ibérica.

Axford, Barrie y Huggins, Richard (2000), "Towards a post-national polity: the emergence of the Network Society in Europe”, Sociological Review, 48, 173-206.

Bajtín, Mijaíl (1998), La cultura popular en la Edad Media y el Renacimiento. El contexto de Françoise Rabelais. Madrid: Alianza.

Barber, Benjamin (1984), Strong Democracy: Participatory Politics for a New Age. Berkeley: University of California Press.

Barber, Benjamin (1998), "Three scenarios for the future of technology and strong democracy", Political science quarterly, 113, 573-589.

Barney, Darin (2000), Prometheus Wired: The hope for democracy in the age of network technology. Chicago: University of Chicago. 
Bateson, Gregory (1972), Steps to an Ecology of Mind: Collected Essays in Anthropology, Psychiatry, Evolution, and Epistemology. Chicago: University Of Chicago Press.

Bauman, Zygmunt (1999), In Search of Politics. Palo Alto: Stanford University Press.

Baumgarten, Britta (2013), "Geração à Rasca and beyond: Mobilizations in Portugal after 12 March 2011", Current Sociology, 61, 457-473.

Bennett, W Lance y Segerberg; Alexandra (2011), "Digital media and the personalization of collective action: Social technology and the organization of protests against the global economic crisis.", Information, Communication \& Society 14.6, 770-799.

Berger, Peter. y Luckmann, Thomas (1996), La construcción social de la realidad. Buenos Aires: Amorrortu.

Best, Steven y Kellner, Douglas (1997), The Postmodern Turn. New York: Guilford.

Bourdieu, Pierre (1989): "Social space and symbolic power”, Sociological Theory, 7, 14-25.

Bourdieu, Pierre (2002): “The forms of capital”, in N. W. Biggart (ed.), Readings in Economic Sociology. Oxford: Blackwell, 280-91.

Candón Mena, José Ignacio (2014), "La batalla de la agenda: de las redes sociales a la agenda mediática, política y electoral”, TecCom Studies, 4, 217-227.

Carpenter, Cherish (2010), “The Obamachine: Technopolitics 2.0”, Journal of Information Technology \& Politics, 7, 216-225.

Castells, Manuel (2009), Comunicación y poder. Madrid: Alianza.

Castells, Manuel. (2012), Redes de indignación y esperanza. Madrid: Alianza.

Castells, Manuel. (2015), "Informationalism, networks, and the network society", in Manuel Castells (ed.) (2004), The network society: a cross-cultural perspective. Northampton, MA: Edward Elgar.

Coleman, Gabriela (2016), Las Mil caras de Anonymous: hackers, activistas, espías y bromistas. Barcelona: Arpa.

Deleuze, Gilles y Guattari, Félix (2002), Mil Mesetas. Valencia: Pre-textos.

Della Porta, Donatella y Tarrow Sidney (2005), Trasnational Protest and Global Activism. Nueva York: Rowman \& Littlefield.

., Kriesi, Hans Peter y Rutch, Dieter (2009), Social Movements in a Globalizing World.

Basingstoke: Palgrave Macmillan.

. y Diani, Mario (2011), Los movimientos sociales. Madrid: CIS/Complutense.

. Snow, David; Klandermans, Bert y McAdam, Doug (Eds.) (2013), The Wiley Blackwell 
Encyclopedia of Social and Political Movements. Londres: Wiley.

Di Salvo, Philip y Negro, Gianluigi (2015), “Framing Edward Snowden: A comparative analysis of four newspapers in China, United Kingdom and United States”, Journalism, Julio 24, 1-18.

Diani, Mario y McAdam, Doug (2003), Social Movements and Networks: Relational Approaches to Collective Action. Oxford: Oxford University Press.

Eagleton, Terry et Bourdieu, Peter (1992): “Doxa and Common Life”, New Left Review, Volume: 1, Issue: 191, 111-12.

Earl, Jennifer et al. (2010), "Changing the World One Webpage at a Time: Conceptualizing and Explaining Internet Activism”, Mobilization, 15, 425-446.

Estanque, Elisio; Costa, Hermes Augusto y Soeiro, José (2013), “The New Global Cycle of Protest and the Portuguese Case", Journal of Social Science Education, 12, 31-40.

Fernández-Albertos, José (2015), Los votantes de Podemos. Del partido de los indignados al partido de los excluidos. Madrid: Catarata.

Fernández Prados, Juan Sebastián (2012), “Ciberactivismo: conceptualización, hipótesis y medida", Arbor, 188, 756, 631-639.

Fraser, Nancy (2007), "Transnationalizing the Public Sphere. On the Legitimacy and Efficacy of Public Opinion in a Post-Westphalian World", In: S. Benhabib, I. Shapiro y D. Petranovich (eds.), Identities, Affiliations, and Allegiances. Cambridge: Cambridge University Press.

Gerbaudo, Paolo (2012), Tweets and the Streets: Social Media and Contemporary Activism. Londres: Pluto.

Ginzberg, Eli (Comp.) (1965), Tecnología y cambio social. México: UTEHA.

Goffman, Erving (1974), Frame Analysis: An Essay on the Organization of Experience. Londres: Harper and Row.

Gravante, Tommaso. (2012), “Las prácticas de apropiación, las nuevas tecnologías y el cambio social. Un estudio de caso: la insurgencia del popular Oaxaca”, Eptic online: revista electrônica internacional de economia política da informação, da comunição e da cultura. 2012 14(. 3): 4462.

Grossman, Lawrence (1995), The Electronic Republic: Reshaping Democracy in the Information Age. Nueva York: Viking.

Gurak, Laura y Logie, John (2003), "Internet Protests, from Text to Web” in M. McCaughey y M. D. Ayers (eds.) (2003): Cyberactivism: Online Activism and Theory and Practice. New York: Routledge, 25-46.

Habermas, Jürgen (1989), The structural transformation of the public sphere. Cambridge: Polity. 
Habermas, Jürgen, Burger, Thomas y Lawrence, Frederick (1990), “The Structural Transformation of the Public Sphere: An Inquiry into a Category of Bourgeois Society.", Contemporary Sociology, Vol. 19, No. 2 (Mar.), 312-316.

Hecht, Gabrielle (2011), Entangled Geographies: Empire and Technopolitics in the Global Cold War. Massachusetts: MIT Press.

Hendricks, Jonh Allen y Kaid, Linda Lee (2011), Techno politics in presidential campaign: new voices, new technologies and new votes. Nueva York: Routledge.

Hindman, Elisabeth y Thomas, Ryan (2014), "When old and new media collide: The case of WikiLeaks", New Media \& Society, 16, 541-558.

Howard, Philip y Hussain, Muzamil (2013), Democracy's Fourth Wave? Digital Media and the Arab Spring. Oxford: Oxford University Press.

Howe, Neil y Strauss, William (2000), Millennials rising: the next generation. Nueva York: Vintage.

Jiménez Melgarejo, Guillermo (2013), “La juventud y los movimientos sociales en el entorno de las nuevas tecnologías”, Revista de Estudios de Juventud, №. 103, 147-159.

Kahn, Richard y Kellner, Douglas (2004), "New Media and Internet Activism: From the 'Battle of Seattle' to Blogging.", New Media \& Society, 6, 87-95.

Kahn, Richard y Kellner, Douglas. (2005), “Oppositional Politics and the Internet: A Critical/Reconstructive Approach", Cultural Politics, Vol 1. No. 1.

Kahn, Richard y Kellner, Douglas. (2007), "Resisting Globalization", in George Ritzer (ed.), The Blackwell Companion to Globalization. London: Blackwell.

Kamarck, Elaine Ciulla y Nye, Joseph S. Jr. (eds.) (2002), Governance.com: Democracy in the Information Age. Washington, D.C.: Brookings.

Klandermans, Bert y Tarrow, Sidney (1988), “Mobilization into Social Movements: Synthesizing European and American Approaches”, International Social Movement Research, 1, 1-38.

Klotz, Audie (2002), "Transnational Activism and Global Transformation: The Anti-Apartheid and Abolitionist Experiences”, European Journal of International Relations, 8 (1), 49-76.

Kuhn, Thomas. S. (2007), La estructura de las Revoluciones Científicas. México D. F.: FCE.

Laclau Ernesto (1996), Emancipación y diferencia. Buenos Aires: Ariel.

Buenos Aires

Lang, Kurt y Engel Lang, Gladys (2009), “Mass Society, Mass Culture and Mass Communication: The Meaning of Mass", International Journal of Communication, 3, 998-1024.

Lévy, Pierre (2001), Cyberdémocratie: Essai de philosophie politique. París: Jacob. 
Mendes, José Manuel y Seixas Ana María (2005), “Acção colectiva e protesto em Portugal: Os movimentos sociais ao espelho dos media (1992-2002)", Revista Critica de Ciências Sociais: Acção Colectiva, Protesto e Cidadania, 72, 99-127.

- y Araújo, Pedro (2013) (orgs.), Os lugares (im) possíveis da cidadania. Estado e risco num mundo globalizado. Coimbra: Almedina.

Medosch, Armin (2016), "Shockwaves in the New World Order of Information and Communication", in Christiane Paul, (edt.), Blackwell Companion to Digital Art. Hoboken, New Jersey: Wiley-Blackwell.

Dan Merceaa, Laura lannellib \& Brian D. Loaderc (2016), “Protest communication ecologies”, Information, Communication \& Society, Volume 19, Issue 3, Special Issue: Protest Communication Ecologies, pages 279-289.

Milan, Stefania (2013), "From social movements to cloud protesting: the evolution of collective identity", Information, Communication \& Society, Volume 18, Issue 8, 2015, Special Issue: Social Media and Protest Identities, 887-900.

Mitchell, Timothy (2002): Rule of Experts Egypt, Techno-politics, Modernity. Berkeley: University of California Press.

Morin, Edgar (2004), “La epistemología de la complejidad”, Gazeta de Antropología, 20, 43 -77. Morozov, Evgeny (2015), La locura del solucionismo -tecnológico. Madrid: Clave Intelectual. Mumford, Lewis (2006), Técnica y civilización. Madrid: Alianza.

Norris, Pippa (2000), A Virtuous Circle: Political Communications in Postindustrial Societies. Cambridge: Cambridge University Press.

Park, Dave; Jankowski, Nick y Jones, Steve (editors) (2011): The Long History of New Media: Technology, Historiography, and Contextualizing Newness. Berlin: Peter Lang.

Razquin, Adriana (2015), “Desbordamientos y viaje hacia la izquierda. Prehistoria del movimiento 15M: de \#Nolesvotes a Democracia Real Ya", Daimon. Revista Internacional de Filosofía, 51-70.

Russell, Bernard Harvey, y Pelto, Pertti J. (1972), Technology and social change. Nueva York: Macmillan.

Sabariego, Jesús (2005), “La globalización de las relaciones entre cultura y política: una nueva ecología social de la identificación", in VA, Investigación de la paz y los Derechos Humanos desde Andalucía. Granada: Eirene, 2005, 437-456.

Sabariego, Jesús. (2007), Los otros derechos humanos. Cultura, Política y Movimientos Sociales en el Foro Social Mundial. Sevilla: Atrapasueños. 
Sabariego, Jesús. (2018): La tecnopolítica de los Recientes Movimientos Sociales Globales. In Santos, Boaventura de Sousa and Mendes, José Manuel (Eds.), Demodiversidade. Belo Horizonte: Autêntica.

Sampedro, Víctor (coord.) (2011), Cibercampaña: cauces y diques para la participación. Las Elecciones Generales de 2008 y su proyección tecnopolítica. Madrid: Complutense.

Sassen, Saskia (2011), “The Global Street: Making the Political”, Globalizations, 8: 5, 573-579.

Santos, Boaventura de Sousa (2015), "Las revueltas mundiales de indignación: su significado para la teoría y para la práctica”, in J. L. Exeni (ed.), Revueltas de indignación y otras conversas. La Paz: Stigma, 17-36.

Santos, Boaventura de Sousa. (2010): Para descolonizar el occidente. Mas allá del pensamiento abismal. Buenos Aires: CLACSO.

Searle, John Rogers (1986), Actos de habla. Madrid: Cátedra.

Santos, Boaventura de Sousa. (1997), La construcción de la realidad social. Barcelona: Paidós Ibérica

Shirky, Clay (2008): Here Comes Everybody: The Power of Organizing Without Organizations. Londres: Penguin.

Sierra, Francisco (2013), Ciudadanía, Tecnología y Cultura. Nodos conceptuales para pensar la nueva mediación digital. Barcelona: Gedisa.

Sierra, Francisco and Gravante, Tommaso (2018). Technopolitics in Latin America. London: Palgrave.

Simões do Paço, António y Varela, Raquel (2015), "The “Memorandum of Understanding” in Portugal and the Portuguese Left.", Socialism and Democracy, 29, 3, 104-114.

Strangelove, Michael (2005), The Empire of Mind: Digital Piracy and the Anti-Capitalist Movement. Toronto: University of Toronto.

Taibo, Carlos (2011), Nada será como antes. Sobre el movimiento 15-M. Madrid: Catarata.

Tascón, Mario y Quintana, Yolanda (2012): Ciberactivismo. Las nuevas revoluciones de las multitudes conectadas. Madrid: Catarata.

Thorsen, Einar; Sreedharan Chindu y Allan, Stuart (2013), "Wikileaks and whistle-blowing: The framing of Bradley Manning.", in Benedetta Brevini; Arne Hintz y Patrick McCurdy (eds): Beyond WikiLeaks: Implications for the Future of Communications, Journalism and Society. Nueva York: Palgrave Macmillan, 101-122.

Tilly, Charles y Tarrow, Sidney (2007), Contentious Politics. Boulder: Paradigm.

Tilly, Charles y Wood Lesley J. (2009), Social Movements, 1768-2008. Boulder: Paradigm. 
Toret, Javier (Coord.) (2013), Tecnopolítica: la potencia de las multitudes conectadas. El sistema red 15M, un nuevo paradigma de la política distribuida. Barcelona: Universitat Oberta de Catalunya.

Touraine, Alain (1978), “Théorie et pratique d'une sociologie de l'action”, Sociologie et sociétés, 10, 149-188.

Treré, Emiliano (2015), “Redescubriendo el poder transformador de la comunicación para el cambio social en la era del Big Data”, Comunicación y Sociedad, Jan-June, 23.

Treré, Emiliano y Mattoni, Alice (2016) Media ecologies and protest movements: main perspectives and key lessons. Information, Communication \& Society 19:3, pages 290-306.

Recebido em: 07.11.2019 / Aprovado em: 27.12.2019 / Publicado em: 27.12.2019

\section{COMO FAZER REFERÊNCIA AO ARTIGO (ABNT):}

SABARIEGO, Jesús. Technopolitical approaches on the Recent Global Social Movements. Revista Eletrônica do Curso de Direito da UFSM, Santa Maria, RS, v. 14, n. 1, e40999, set./dez. 2019. ISSN 1981-3694. DOI:

http://dx.doi.org/10.5902/1981369440999. Disponível em: https://periodicos.ufsm.br/revistadireito/article/view/40999 Acesso em: dia mês. ano.

Direitos autorais 2019 Revista Eletrônica do Curso de Direito da UFSM

Editores responsáveis: Rafael Santos de Oliveira e Angela Araujo da Silveira Espindola

Esta obra está licenciada com uma Licença Creative Commons Atribuição-NãoComercial-SemDerivações 4.0 Internacional.

\section{SOBRE O AUTOR}

\section{JESÚS SABARIEGO}

The present work is a result a Postdoctoral Fellowship funded by the Portuguese Foundation for Science and Technology (FCT) developed since 2015 at the Centre for Social Studies of the University of Coimbra (Portugal) and the Research Group on Political Communication and Social Science (COMPOLÍTICAS) of the University of Seville (Spain). Centro de Estudos Sociais, University of Coimbra, Portugal and University of Seville (Spain). 